\title{
EFEKTIFITAS KOMUNIKASI INTERPERSONAL SISWA MELALUI METODE DISKUSI BUZZ GROUP DALAM PEMBELAJARAN PAI KELAS VI SDN BANDAR KIDUL 1
}

\author{
Moh. Latiful Umam \\ Program Pascasarjana Institute Agama Islam Tribakti Kediri
}

\begin{abstract}
Abstrak
Penelitian ini di bingkai dalam topik besar Kurikulum Pendidikan yang secara khusus meliPenelitian ini dibingkai dalam topik besar Metode Pembelajaran yang secara khusus melihat praktek pembelajaran di SDN Bandar Kidul 1 Kediri dari komunikasi interpersonal siswa dalam kelas dengan menggunakan metode buzz group. Penelitian ini diharapkan memiliki nilai praktis terhadap pembelajaran PAI.

Permasalahan yang diajukan dalam penelitian ini meliputi: 1). Bagaimana pelaksanaan metode Diskusi Buzz Group pada Mata Pelajaran PAI di kelas VI SDN Bandar Kidul 1 Kediri, dan 2). Bagaimana efektifitas Komunikasi Interpersonal siswa pada Mata Pelajaran PAI dalam metode Diskusi Buzz Group di kelas VI SDN Bandar Kidul 1 Kediri.

Lokasi penelitian ini SD Negeri Bandar Kidul 1 Kediri. Sampel yang digunakan dalam penelitian ini adalah siswa-siswi kelas VI SD Negeri Bandar Kidul 1 Kediri.

Jenis pendekatan penelitian ini adalah penelitian kualitatif. Teknik pengumpulan data yang digunakan (1). Observasi, (2). Wawancara, (3). Tes, (4). Dokumentasi. Dan teknik analisa data yang digunakan adalah reduksi data, paparan data dan penyimpulan. Maka data terkumpul dianalisis dengan bekal senjata intelektual berupa teori sebagaimana ditampilkan dalam Bab II untuk mendapatkan berbagai uraian interperaktif sesuai kaidah penelitian ilmiah yang logis dan rasional atas data yang dikumpulkan.

Akhirnya, penelitian ini berhasil memperoleh temuan sesuai pertanyaan permasalahan yang pada garis besarnya dapat disimpulkan sebagai berikut. 1)pelaksanaan metode diskusi buzz group berjalan lancar, antusias dari anak-anak sangat baik serta memiliki kemanfaatan yang baik dalam kemajuan pemahaman siswa kelas VI pada materi pendidikan agama islam bab sholat tarawih. 2) efektifitasanya siswa pada materi pendidikan agama Islam ada kemajuan dengan menggunakan metode diskusi buzz group serta memperlancar siswa dalam komunikasi di kelas dan memahami materi pelajaran.
\end{abstract}

Kata Kunci: Komunikasi Interpersonal, Mata Pelajaran PAI, Metode Diskusi Buzz Group

\section{A. Konteks Penelitian}

Kegiatan komunikasi interpersonal merupakan kegiatan sehari-hari yang paling banyak dilakukan oleh manusia sebagai mahluk sosial. Sejak bangun tidur di pagi hari sampai tidur lagi di larut malam, sebagian besar dari waktu kita digunakan untuk berkomunikasi dengan manusia yang lain. Dengan demikian kemampuan berkomunikasi merupakan suatu kemampuan yang paling dasar.
Akan tetapi dalam kehidupan seharihari kita sering mengalami perbedaan pendapat, ketidaknyamanan situasi atau bahkan terjadi konflik yang terbuka yang disebabkan adanya kesalahfahaman dalam berkomunikasi. Menghadapi situasi seperti ini, manusia baru akan menyadari bahwa diperlukan pengetahuan mengenai bagaimana cara berkomunikasi yang baik dan efektif.yang harus dimiliki seorang manusia. 
Efektifitas seorang komunikator dapat dievaluasi dari sudut sejauhmana tujuantujuan tersebut dicapai. Persyaratan untuk keberhasilan komunikasi adalah mendapat perhatian. Jika pesan disampaikan tetapi penerima mengabaikannya, maka usaha komunikasi tersebut akan gagal. Keberhasilan komunikasi juga tergantung pada pemahaman pesandan penerima. Jika penerima tidak mengerti pesan tersebut,maka tidaklah mungkin akan berhasil dalam memberikan informasi atau mempengaruhinya. Bahkan jika suatu pesan tidak dimengerti, penerima mungkin tidak meyakini bahwa informasinya benar, sekalipun komunikator benar-benar memberikan arti apa yang dikatakan.

Agar komunikasi dapat berjalan lancar, maka dibutuhkan keahlian dalam berkomunikasi( communication skill). Dan tidaklah semua orang memiliki communication skill. Banyak orang yang berkomunikasi hanya mengandalkan gaya yang dipakai sehari-hari. Mereka menganggap cara komunikasi yang mereka pakai sudah benar. Padahal kalau dicermati masih banyak kesalahan dalam berkomunikasi.

Berangkat dari konteks di atas maka peneliti merasa perlu untuk mengadakan penelitian di SDN Bandar Kidul 1 Kota Kediri dikarenakan masih banyak siswa siswi yang pasif dan kurang paham dalam menerima materi yang disampaikan guru, dengan mengangkat judul tesis "Efektifitas

Komunikasi Interpersonal Siswa Kelas VI SDN Bandar Kidul 1 Melalui Metode Diskusi Buzz Group Dalam Pembelajaran PAI", maka kami melakukakan berbagai metode penelitian agar bisa mendapatkan hasil penelitian yang maksimal.

\section{B. Fokus Penelitian}

1. Bagaimana pelaksanaan metode Diskusi Buzz Group pada Mata Pelajaran PAI di kelas VI SDN Bandar Kidul 1 Kediri?
2. Bagaimana efektifitas Komunikasi Interpersonal siswa pada Mata Pelajaran PAI dalam metode Diskusi Buzz Group di kelas VI SDN Bandar Kidul 1 Kediri?

\section{Tujuan Penelitian}

1. Untuk mengetahui pelaksanaan metode Diskusi Buzz Group pada Mata Pelajaran PAI di kelas VI SDN Bandar Kidul 1 Kediri.

2. Untuk mengefektifitaskan Komunikasi Interpersonal siswa pada Mata Pelajaran PAI dalam metode Diskusi Buzz Group di kelas VI SDN Bandar Kidul 1 Kediri.

Tinjauan Komunikasi Interpersonal Siswa

Komunikasi intrapersonal yaitu komunikasi yang terjadi dalam diri sendiri. Dalam diri kita masing-masing terdapat komponen-komponen komunikasi, seperti : sumber, pesan, chanel, penerima dan balikan. Jika dalam komunikasi intrapersonal hanya seorang yang terlibat, sedangkan dalam komunikasi interpersonal melibatkan dua orang atau lebih. Meskipun dalam komunikasi intrapersonal penyampaian pesan mulai dan berakhir dalam diri individu masingmasing, namun komunikasi intrapersonal mempengaruhi komunikasi intrapersonal dan hubungan dengan orang lain. Wenburg dan Wilmat menyatakan bahwa persepsi individu tidak dapat dicek oleh orang lain, tetapi semua arti atribut pesan ditentukan oleh masingmasing individu. Persepsi seseorang memegang peranan penting dalam menginterpretasikan pesan. ${ }^{1}$

Semua pesan diciptakan bermula dalam diri kita. Kita bereaksi menurut perbedaan personal kita terhadap pesan disekeliling kita. Inilah yang membuat komunikasi kejadian yang bersifat personal, karena tidak pernah dapat dipisahkan dari interaksi kita dengan orang lain.

Jadi komunikasi interpersonal adalah proses pertukaran informasi diantara seseorang

1 Rakhmat, Jalaludin.1966.Psikologi Komunikasi. Bandung:Remaja Rosdakarya, hlm.30. 
dengan paling kurang satu orang lainnya atau biasanya diantara dua orang yang dapat langsung diketahui balikannya. Dengan bertambahnya orang yang terlibat dalam komunikasi, menjadi bertambahlah persepsi orang lain dalam kejadian komunikasi, sehingga bertambah komplekslah komunikasi tersebut. ${ }^{2}$

\section{Ciri-ciri Komunikasi Interpersonal}

Ada lima aspek yang merupakan ciri - ciri dari komunikasi interpersonal, antara lain : a. Komunikasi interpersonal biasanya terjadi secara spontan dan tanpa tujuan terlebih dahulu. Maksudnya, bahwa biasanya komunikasi interpersonal terjadi secara kebetulan tanpa rencana sehingga pembicaraan terjadi secara spontan. b. Komunikasi interpersonal mempunyai akibat yang direncanakan maupun tidak terencana. c. Komunikasi interpersonal biasanya berlangsung berbalasan. Salah satu ciri khas komunikasi interpersonal adalah adanya timbale balik bergantian dalam saling member maupun menerima informasi antara komunikator dan komunikan secara bergantian sehingga tercipta suasan dialogis. ${ }^{3}$ d. Komunikasi interpersonal biasanya dalam suasana kedekatan atau cenderung menghendaki keakraban. Untuk mengarh kepada suasana kedekatan atau keakraban tentunya kedua belah pihak yaitu komunikator dan komunikan harus berani membuka hati, siap menerima keterus- terangan pihak lain. e. Komunikasi interpersonal dalam pelaksana annya lebih menonjol dalam pendekatan psikologis daripada unsure sosiologisnya. Hal ini karena adanya unsur kedekatan atau keakraban yang terbatas pada dua atau dengan paling banyak tiga individu saja yang terlibat. Sehingga faktor-faktor yang mempengruhi kejiwaan seseorang

2 Cangara, Hafied. 2008. Pengantar IImu Komunikasi. Jakarta : Raja Grafindo, hlm 35-37

3 Muhammad, Arni.1995.Komunikasi organisasi. Jakarta:Bumi Aksara,hlm.25 lebih mudah terungkap dalam komunikasi tersebut ${ }^{4}$

\section{Tujuan Komunikasi Interpersonal}

Komunikasi interpersonal mungkin mempunyai beberapa tujuan. Di sini akan dipaparkan 6 tujuan, antara lain:

\section{a. Menemukan Diri Sendiri}

Salah satu tujuan komunikasiinterpersonal adalah menemukan personal atau pribadi. Bila kita terlibat dalam pertemuan interpersonal dengan orang lain kita belajar banyak sekali tentang diri kita maupun orang lain. Komunikasi interpersonal memberikan kesempatan kepada kita untuk berbicara tentang apa yang kita sukai, atau mengenai diri kita. Adalah sangat menarik dan mengasyikkan bila berdiskusi mengenai perasaan, pikiran, dan tingkah laku kita sendiri. Dengan membicarakan diri kita dengan orang lain, kita memberikan sumber balikan yang luar biasa pada perasaan, pikiran, dan tingkah laku kita.

\section{b. Menemukan Dunia Luar}

Hanya komunikasi interpersonal menjadikan kita dapat memahami lebih banyak tentang diri kita dan orang lain yang berkomunikasi dengan kita. Banyak informasi yang kita ketahui datang dari komunikasi interpersonal, meskipun banyak jumlah informasi yang datang kepada kita dari media massa hal itu seringkali didiskusikan dan akhirnya dipelajari atau didalami melalui interaksi interpersonal.

\section{c. Membentuk Dan Menjaga Hubungan Yang Penuh Arti}

Salah satu keinginan orang yang paling besar adalah membentuk dan memelihara hubungan dengan orang lain. Banyak dari waktu kita pergunakan dalam komunikasi interpersonal diabadikan untuk membentuk dan menjaga hubungan sosial dengan orang lain.

\footnotetext{
4 Muhammad, Arni.1995.Komunikasi organisasi. Jakarta:Bumi Aksara,hlm.25
} 


\section{Pendidikan Agama Islam}

Pendidikan merupakan kata yang sudah sangat umum. Karena itu, boleh dikatakan bahwa setiap orang mengenal istilah pendidikan. Begitu juga Pendidikan Agama Islam ( PAI ). Masyarakat awam mempersepsikan pendidikan itu identik dengan sekolah, pemberian pelajaran, melatih anak dan sebagainya. Sebagian masyarakat lainnya memiliki persepsi bahwa pendidikan itu menyangkut berbagai aspek yang sangat luas,termasuk semua pengalaman yang diperoleh anak dalam pembetukan dan pematangan pribadinya, baik yang dilakukan oleh orang lain maupun oleh dirinya sendiri. Sedangkan Pendidikan Agama Islam merupakan pendidikan yang didasarkan pada nilai-nilai Islam dan berisikan ajaran Islam. $^{5}$

Tujuan pendidikan islam merupakan hal yang dominan dalam pendidikan, rasanya penulis perlu mengutif ungkapan breiter, bahwa pendidikan adalah persoalan tujuan dan fokus. Mendidika anak berarti bertindak dengan tujuan agar mempengaruhi perkembangan anak sebagai seseorang secarah utuh. ${ }^{6}$

Pendidikan agama Islam di sekolah bertujuan untuk menumbuhkan dan meningkatkan keimanan melalui pemberian dan pemupukan pengetahuan, penghayatan, pengamalan, serta pengalaman peserta didik tentang agama Islam sehingga menjadi manusia muslimyang terus berkembang dalam hal keimanan, ketakwaannya, berbangsa dan bernegara, serta untuk dapat melanjutkan pada jenjang pendidikan yang lebih tinggi.

\section{Peran pendidikan agama Islam}

Pendidikan secara kulturan pada umumnya berada dalam lingkup peran, fungsi dan tujuan yang tidak berbeda. Semuanya hidup dalam upaya yang bernaksud mengankat dan menegakkan martabat manusia melalui

5 Mira Gustina, (2014), Pengertian dan tujuan Pendidikan Agama Islam Menurut para Ahli, http://miragustina90.blogspot.co.id/2014/03/pengertian-dan-tujuanpendidikan-agama.html, diakses tanggal 18-09-2016

6 Aminuddin, dkk. (2005). Pendidikan Agama Islam untuk Perguruan Tinggi Umum. Bogor: Ghalia Indonesia denganUniversitasIndonusiEsa Unggul.hlm 145 transmisi yang dimilikinya, terutama dalam bentuk transfer of knowledge dan transfer of values.

Dalam konteks ini secara jelas juga menjadi sasaran jangkauan pendidikan Islam, merupakan bagian dari system pendidikan nasional, sekalipun dalam kehidupan bangsa Indonesia tampak sekali eksistensinya secara cultural. Tapi secara kuat ia telah berusaha untuk mengambil peran yang kompetitif dalam setting sosiologis bangsa, walaupun tetap saja tidak mampu menyamai pendidikan umumn yang ada dengan otonomi dan dukungan yang lebih luas, dalam mewujudkan tujuan pendidikan secara nyata.

Sebagai pendidikan yang berlebel agama, maka pendidikan Islam memiliki transmisi spritual yang lebih nyata dalam proses pengajarannya dibanding dengan pendidikan umum, sekalipun lembaga ini juga memiliki muatan serupa. Kejelasannya terletak pada keinginan pendidikan Islam untuk mengembangkan keseluruhan aspek dalam diri anak didik secara berimbang, baik aspek intelektual, imajinasi dan keilmiahan, kulturan serta kepribadian. Karena itulah pendidikan Islam memiliki beban yang multi paradigm, sebab berusaha memadukan unsure profane dan imanen, dimana dengan pemaduan ini, akan membuka kemungkinan terwujudnya tujuan inti pendidikan Islam yaitu melahirkan manusia-manusia yang beriman dan berilmu pengetahuan, yang satu sama lainnya saling menunjang.

\section{Tujuan dan fungsi pendidikan agama Islam}

Secara umum, tujuan pendidikan agama islam terbagi kepada: tujuan umum, tujuan sementara, tujuan akhir, dan tujuan operasional, tujuan umum adalah tujuan yang akan dicapai denagan semua kegiatan pendidikan baik dengan pengajaran atau dengan cara lain. Tujuan sementara adalah tujuan yang akan dicapai setelah anak didik diberi sejumlah pengalaman tertentu yang direncanakan dalam sebuah kurikulum. Tujuan akhir adalah tujuan yang dikehendaki agar peserta didik manusiamanusia yang sempurna (insane kamil). 
Sedangkan tujuan operasional adalah tujuan praktis yang akan dicapai dengan sejumlah kegiatan pendidikan tertentu. ${ }^{7}$

Pendidikan Islam adalah pendidikan yang sadar dan bertujuan dan Allah meletakkan azas-azasnya bagi seluruh manusia di dalam syari'at ini. Oleh sebab itu, sudah semestinya mengkaji pendidikan terlebih dahulu menjelaskan tujuannya yang luhur dan luas, yang telah ditetapkan oleh Allah bagi seluruh aktititas manusia. karena tujuan merupakan kompas, barometer sekaligus evaluator dalam penyelenggaraan sutau pendidikan.

\section{Metode Penelitian}

Pendekatan penelitian ini adalah pendekatan kualitatif, yaitu suatu penelitian yang berusaha mengungkap gejala secara menyeluruh dan sesuai dengan konteks melalui pengumpulan data dari latar alami dengan memanfaatkan diri sebagai isntrumen kunci. Dengan pendekatan penelitian deskriptif kualitatif ini data yang dihasilkan adalah data berupa ucapan atau penulisan dan perilaku yang diamati dari orang-orang (obyek) itu sendiri.

Jenis penelitian yang digunakan dalam penelitian ini adalah studi kasus, mencoba mengkaji secara mendalam dan terperinci dari suatu latar belakang, yang ada dalam penelitian ini dilakukan untuk meneliti tentang Upaya Meningkatkan Komunikasi Interpersonal Siswa Kelas VI pada Mata Pelajaran Pendidikan Agama Islam dalam Metode Diskusi Buzz Group di SDN Bandar Kidul 1 Kediri.

\section{Pelaksnaan pembelajaran menggunakan metode diskusi Buzz group dalam komunikasi interpersonal siswa}

Dari data pengamatan aktivitas siswa di atas dapat diuraikan bahwa di antara 20 - 30 siswa mendengarkan dan memusatkan perhatian pada guru itu lebih baik. Lebih dari 30 dapat bekerjasama dengan kelompoknya dengan baik. Lebih dari 30 siswa dapat berkomunikasi dengan siswa lain dalam

7 Aminuddin, dkk. (2005). Pendidikan Agama Islam untuk Perguruan Tinggi Umum. Bogor: Ghalia Indonesia dengan Universitas IndonusiEsa Unggul.hIm 147 kelompoknya. Di antara 20 - 30 siswa berani bertanya dengan menggunakan bahasa yang benar ketika tidak mengerti. Di antara $20-30$ siswa mampu memberikan masakan jawaban yang masuk akal dan relevan dengan persoalan. Lebih dari 30 siswa mampu melakukan tanya jawab dengan sesama kelompoknya dengan bahasa yang wajar. Di antara 20 - 30 siswa bisa tampil berani di depan kelas untuk mempresentasikan hasil diskusinya, lebih dari 30 siswa mampu mengemukakan pendapatnya ketika diskusi. Lebih dari 30 siswa memahami penjelasan dari siswa dan guru, lebih dari 30 siswa mampu mengarahkan kelompoknya kepada pembahasan yang sebenarnya. Dengan demikian menunjukkan bahwa efektifitas komunikasi interpersonal siswa kelas VI SDN Bandar Kidul 1 melalui metode diskusi Buzz Group dalam pembelajaran PAI tergolong baik.

\section{Efektivitas metode diskusi Buzz group dalam komunikasi interpersonal} siswa kelas VI SDN Bandar Kidul

\section{B. Analisis Data}

Dari data yang sudah terkumpul, maka langkah selanjutnya memasuki tahap analisa data sebagaimana yang dijelaskan pada bab pendahuluan bahwa teknik analisa data yang dipakai yakni menggunakan analisis deskriptif. Di mana analisis ini dilakukan sampai pada taraf deskriptif artinya menganalisis dan menyajikan fakta secara sistematis sehingga lebih mudah untuk dipahami dan disimpulkan.

1. Pelaksanaan Metode Diskusi Buzz Group pada Mata Pelajaran PAI di Kelas VI SDN Bandar Kidul 1 Kediri.

a. Model pembelajaran yang dilakukan oleh guru dalam menggunakan metode diskusi Buzz group dalam upaya meningkatkan kemampuan komunikasi interpersonal siswa kelas VI.

Berdasarkan dari sebuah program pembelajaran yang dilakukan oleh SDN Bandar Kidul 1 khususnya, tatkala pada prinsipnya seorang pengajar sebelum melakukan proses belajar mengajar sudah 
diharuskan mempersiapkan program materi yang akan diajarkan dalam bentuk RPP (Rancangan Program Pembelajaran), jadi guru di sini ketika mengajar mampu mengaplikasikan secara sistematis dan lebih matang.

Sesuai penerapan yang ada dalam proses belajar mengajar bahwa dalam menggunakan metode diskusi Buzz group guru pada mulanya cenderung lebih aktif dan memberikan pertanyaan di setiap awal pelajaran ketika berlangsung. Di sini guru memberikan pertanyaan tentang permasalahan yang akan dibahas, atau materi pelajaran yang telah lalu. Bahwa keaktifan siswa mulai nampak pada saat proses diskusi berlangsung itu terlihat para siswa aktif berkomunikasi dengan siswa lain, bertanya, menjawab, mengemukakan pendapat, presentasi hal itu semua dikarenakan metode diskusi buzz group merupakan sarana bagi siswa untuk aktif dalam komunikasi.

b. Faktor pendukung dan penghambat yang mempengaruhi dalam efektifitas komunikasi interpersonal siswa kelas VI SDN Bandar Kidul 1 melalui metode diskusi Buzz Group dalam pembelajaran PAI.

\section{a. Faktor pendukung}

Salah satu bentuk faktor pendukung dalam proses belajar mengajar mengenai efektifitas komunikasi interpersonal siswa kelas VI SDN Bandar Kidul 1 melalui metode diskusi Buzz Group dalam pembelajaran PAI diantaranya : kondisi kelas yang cukup nyaman, media yang cukup, kondisi siswa dan guru yang bugar dan fit, adanya respon yang kuat dari guru atau siswa kepada siswa. Ketenangan dalam belajar akan meluncurkan proses belajar mengajar dengan diskusi buzz group.

Kalau melihat dari hasil interview yang berada pada paparan data dapat disimpulkan bahwa metode diskusi buzz group memang benar dapat mengaktifikan para siswa terutama dalam hal komunikasi serta dapat dijadikan sebagai metode yang bersifat primer dalam proses pembelajaran di bandingkan dengan metode yang lain.

b. Faktor penghambat

Mengenai faktor penghambat di dalam proses belajar mengajar berlangsung di dalam kelas dengan menggunakan efektifitas komunikasi interpersonal siswa kelas VI melalui metode diskusi Buzz Group dalam pembelajaran PAI diantaranya, adanya siswa yang mempunyai motivasi terpendam, siswayang memiliki karakter pemalas dan siswa yang hiper pasif, malu serta kurang percaya diri.

Melihat faktor penghambat di atas secara tidak langsung dapat menganggu terhadap proses belajar lebih tepatnya dalam diskusi. Dengan hal ini sehingga menjadi tugas bagi guru yang paling prinsipil, sebab seorang guru tanpa memiliki kreatifitas, skill serta pengalaman dalam mengajar serta sikap sabar dan rajin sehingga proses penerapan metode diskusi buzz group dapat berlangsung sesuai hasil yang ingin di capai. Faktor penghambat lain tingkat kekurangan guru dalam menguasai ilmu psikologi belajar, hal semacam ini menjadi bentuk kelemahan yang menjadikan kualitas pendidikan mengakibatkan kemerosotan dan kegagalan. Sebagaimana guru yang terampil, sukses dan kreatif, manakalah dapat menguasai ilmu psikologi belajar serta teknisnya baik secara teori maupun praktek. Yang pada akhirnya tujuan belajar yang tercantum dalam visi dan misi dapat terealisasi dengan penuh tanggung jawab.

2. Efektifitas Komunikasi Interpersonal Siswa pada Mata Pelajaran PAI dalam Metode Diskusi Buzz Group di Kelas VI SDN Bandar Kidul 1 Kediri. 
Melihat hasil metode diskusi buzz group dalam efektifitas komunikasi interpersonal siswa kelas VI diantaranya : mampu mengembangkan citra anak menjadi lebih kreatif, cakap, tanggap, dalam hal berkomunikasi. Hal ini kalau di korelasikan pada masa sekarang memang cocok, sebab merupakansalah satu target yang diinginkan lulusan sekolah dasar negeri, khususnya SDN Bandar Kidul 1 kelas VI diharapkan peserta didiknya paling tidak mampu cakap dalam berkomunikasi dengan orang lain serta sopan santun dalam mengucapkannya.

Realita masyarakat membuktikan bahwa orang pendidikan itu biasanya menggunakan bahasa yang sopan dalam bertutur kata dan menggunakan bahasa yang baik berbeda dengan orang yang berlatar belakang di sebut orang pagar, anak jalanan biasanya menggunakan bahasa apa adanya dalam artinya suatu yang ia ingin mengungkapkan langsung dibicarakan tanpa mempertimbangkan terlebih dahulu apakah itu buruk, jorok dan sebagainya.

Secara rasional di dalam sekolah tentunya guru sering mengajari anak didiknya bagaimana berkomunikasi dengan orang lain dengan cara yang baik, lantas bagaimana berkomunikasi dengan orang yang lebih tua atau muda. Tentunya berbeda. Tentunya dengan adanya latihan dalam berkomunikasi dengan orang lain melalui proses pembelajaran diskusi buzz group. Terlebih jika dalam kelas VI SDN Bandar Kidul 1 hubungan guru dengan siswa dan siswa ke siswa komunikasi maka indikator hasilya memuaskan.

Tujuan efektifitas komunikasi interpersonal siswa kelas VI melalui metode diskusi Buzz Group dalam pembelajaran PAI.

Adapun tujuan bahwa siswa dapat mengembangkan keterampilan dan keberanian untuk mengemukakan pendapat sendiri secara jelas dan terarah, mencari kebenaran secara jujur melalui pertimbangan pendapat yang mungkin saja berbeda yang satu dengan yang lainnya. Belajar menemukan kesepakatan pendapat melalui musyawarah karena masalahnya telah di mengerti dan bukan karena paksaan dan para siswa mendapatkan informasi yang berharga dari teman dalam diskusi.
Bahwasannya kalau mengacu pada tujuan efektifitas komunikasi interpersonal siswa kelas VI melalui metode diskusi Buzz Group dalam pembelajaran PAI,anak secara substansi sudah dapat dikatakan relevan. Sebab dalam metode tersebut memiliki out put yaitu dapat mewujudkan, membina siswa menjadi lebih cakap, tanggap, terampil dan cerdas dalam hal berkomunikasi serta memahami salah satu bentuk objek keilmuan. Dan hal ini sudah merupakan bagian dari wujud dan cita-cita sebuah bangsa.

Produk yang dihasilkan merupakan tipe pertama yang selanjutnya dievaluasi. Evaluasi yang dilakukan adalah evaluasi ahli, evaluasi satu-satu, evaluasi kelompok kecil, dan uji lapangan. Hasil evaluasi ahli pada tipe pertama secara keseluruhan sudah cukup valid akan tetapi masih terdapat kekurangan terutama ditinjau dari aspek materi sehingga perlu direvisi. Sedangkan dari sudut pandang siswa pada evaluasi satu-satu (one-to-one evaluation) kekurangan lebih terfokus pada kesempatan berpendapat tentang materi yang ada.

Hasil dari revisi didapat produk yang disebut tipe kedua. Tipe kedua selanjutnya dievaluasi dengan sekelompok kecil siswa (small group evaluation). Hasil evaluasi menunjukkan bahwa sebagian besar siswa sudah memahami cara belajar menggunakan metode diskusi buzz group ini dan dapat menggunakan diskusi buzz group dalam pembelajaran, siswa dapat menggunakan petunjuk yang ada, mendengarkan penjelasan guru, dan menyelesaikan evaluasi dengan baik. Maka secara umum dapat dikatakan bahwa tipe ketiga merupakan tipe yang valid dan praktis.

\section{A. Kesimpulan}

Berikut ini kami sajikan kesimpulan dari hasil penelitian, sebagai berikut:

1. Pelaksanaan Metode Diskusi Buzz Group pada Mata Pelajaran PAI di kelas VI SDN Bandar Kidul 1 Kediri

Penerapan metode diskusi buzz group selama ini tidak hanya terjadi secara personal saja, akan tetapi juga melibatkan sarana. Misalnya siswa mengamati terlebih 
dahulu gambar tersebut, kemudian para siswa mengutamakan dengan bentuk kalimat selain itu juga dengan memakai televisi atau $\mathrm{CD}$ mengenai sebuah cerita sehingga di situlah terjadi sebuah interaksi komunikasi interpersonal. Kalau hal ini sudah terbiasa maka siswa akan terbiasa berani mengungkap ide-idenya dalam diskusi buzz group. Dengan demikian, komunikasi interpersonal yang berjalan dapat mengenai antara komunikator dengan komunikan.

2. Efektifitas Komunikasi Interpersonal siswa pada Mata Pelajaran PAI dalam metode Diskusi Buzz Group di kelas VI SDN Bandar Kidul 1 Kediri, sebagai berikut:

Secara rasional di dalam sekolah tentunya guru sering mengajari anak didiknya bagaimana berkomunikasi dengan orang lain dengan cara yang baik, lantas bagaimana berkomunikasi dengan orang yang lebih tua atau muda. Tentunya berbeda. Tentunya dengan adanya latihan dalam berkomunikasi dengan orang lain melalui proses pembelajaran diskusi buzz group. Terlebih jika dalam kelas VI SDN Bandar Kidul 1 hubungan guru dengan siswa dan siswa ke siswa komunikasi maka indikator hasilya memuaskan.

\section{DAFTAR PUSTAKA}

Abdurrahman. (1988) Ilmu Pendidikan Sebuah Pengantar dengan Pendekatan Islam, Cet.I; al-Qushwa, Jakarta.

Abizar. (2008) Interaksi Komunikasi dan Pendidikan. Padang : UNP Press

Ahmad Izzuddin, al-Bayyanu. (1987) Pendidikan Agama Bagi Anak, Pustaka Amani, Jakarta.

Al-Abrasyi, M. Athiyah. (1970) Dasar-dasar Pendidikan Islam, Cet.IV; Bulan Bintang, Jakarta.

Al-Gazali, Imam. (1966) Ikhtisar
Ihya'ulumuddin, (terjemahan), Cet.I; al-Falah, Yogyakarta.

Ali. (1990) Buku Pedoman Profil Sekolah Dasar Negeri Bandar Kidul 1 Kediri, Kediri: Rajawali

Ali, Muhammad. (1987) Guru dalam Proses Belajar Mengajar. Bandung: Sinar Baru Algesindo.

Al-Qahthani, Sa'id bin Ali bin Wahf. (2002) Kumpulan Shalat Sunnah dan Keutamaannya. Terj. oleh Abu Umar Basyir dkk. Jakarta: Darul Haq

Aminuddin, dkk. (2005) Pendidikan Agama Islam untukPerguruanTinggiUmum. Bogor: Ghalia Indonesia denganUniversitasIndonusiEsa Unggul.

Anggota IKAPI. (2009) Undang-Undang SISDIKNAS Sistem Pendidikan Nasional.Bandung: Fokusmedia

Anonim. (2008) Sumber Ilmu Pengetahuan dalam Islam, blogspot : Al-Ikhwan.net.

Arifin, H.M. (1995) KapitaSelektaPendidikan - Islam danUmum. Jakarta:Bumi Aksara.

AW Suranto. (2011) Komunikasi Interpersonal. Yogyakarta: Graha Ilmu.

Burhan Bungin. (2003) Analisis Data Penelitian Kualitatif, (Jakarta: Raja Grafindo Persada.

Cangara, Hafied. (2008) Pengantar Ilmu Komunikasi. Jakarta : Raja Grafindo

Deddy Mulyana, (2005) Ilmu Komunikasi: Suatu Pengantar, Bandung: Remaja Rosdakarya.

Departemen Agama Republik Indonesia. (2004) Al-Qur'an dan Terjemahnya, CV Karya Insan Indonesia (KARINDO) Jakarta.

Departemen Agama RI. (1984) AlQur'an dan Terjemahnya. Jakarta: Departemen Agama RI

Dimyati dan Moedjiono. (1992) Strategi Belajar Mengajar. Depdikbud Dirjen Dikti: Proyek Pembinaan Tenaga Kependidikan 
Djamarah, Syaiful Bahri. (2002) Strategi Belajar Mengajar. Jakarta: Rineka Cipta.

Dr. E. Mulyasa, M.Pd. (2005) Menjadi Kepala Sekolah Professional (Dalam Konteks Menyukseskan MBS Dan KBK). PT REMAJA ROSDAKARYA. Bandung. Cet. Kelima. Januari.

Drs. Hendiyat Soetopo., dan Drs. Wasty Soemanto. (1984) Kepemimpinan dan Supervisi Pendidikan. PT. BINA AKSARA (Anggota IKAPI).

Effendy, Onong Uchjana. (2007) Ilmu Komunikasi dan Praktek. Bandung : Rosdakarya

Hasibuan dan Moedjiono. (2004) Proses Belajar Mengajar, Bandung : PT Rosda Karya

Hidayat, Dasrun. (2012) Komunikasi Antarpribadi dan Medianya. Yogyakarta : Graha Ilmu.

Hisyam dkk. (2008) Strategi Pembelajaran Aktif, Yogyakarta : Pustaka Insani Madani

http://almuttaqintegal.blogspot.co.id/2014/04/ shalat-tarawih-dan-witir.html

http://ardhiansyah221.blogspot.co.id/2012/03/ pengertian-tujuan-pendidikan-agama. html

http://miragustina90.blogspot.co.id/2014/03/ pengertian-dan-tujuan-pendidikanagama.html

http://www.eurekapendidikan.com/2015/02/ metode-diskusi-buzz-group.html

https://ilmucerdaspendidikan.wordpress. com/2011/03/12/85/

Idris, Muh. (2009) "Pembaruan Pendidikan Islam dalam Konteks Pendidikan Nasional," Lentera Pendidikan, XII No. 1: 13-32

Jalaludin Rakhmat, (1994) Psikologi Komunikasi, Bandung: Remaja Rosdakarya

Joko Subagyo. (1977) Metodologi Penelitian Dalam Teori Dan Praktek, Jakarta:
Rineka Cipta.

Koentjaraningrat. (1986) Metode-Metode Penelitian Masyarakat, Jakarta. PT. Gramedia

Komala, Lukiati. (2009) Ilmu Komunikasi: Perspektif, Proses, dan Konteks. Bandung: Widya Padjadjaran

Lexy J. Moleong. (2003) Metode Penelitian Kualitatif, Bandung, Remaja Rosda Karya.

Moh. Nasir. (2003) Metode Penelitian, Jakarta, Ghalia Indonesia

Muhammad, Arni.(1995) Komunikasi organisasi.Jakarta:Bumi Aksara.

Mukhtar, dkk.. (2002) Pendidikan Anak Bangsa :Pendidikan Untuk Semua, Cet.I; Jakarta: Nimas Multima.

Pribadi, B. (2009) Model Desain Sistem Pembelajaran. Jakarta: Dian Rakyat

Rahim, Husni. (2002) Pendidikan Islam di Indonesia Keluar dari Eksklusivisme dalam Pendidikan untuk Masyarakat Indonesi Baru, Jakarta: Grasindo

Rakhmat, Jalaudin.(1966) Psikologi Komunikasi.Bandung:Remaja Rosdakarya

Santrock, Jhon W. (1996) Psikologi Pendidikan. Jakarta: Rajawali Press.

Sugiyono. (2011) Metode Penelitian Kombinasi (Mixed Methods), Bandung: Alfabeta

Sumantri, Mulyanidan Permana, Johar. (2001) Strategi Belajar Mengajar. Bandung: Maulana

Suprijanto. (2007) Pendidikan Orang Dewasa, Jakarta : PT. Bumi Aksara

Tim Redaksi Nuansa Aulia. (2003) Undangundang Republik Indonesia No. 20 Tahun 2003 Tentang Sistem Pendidikan Nasional 2003 Beserta Penjelasannya, Jakarta: Cemerlang.

Trianto. (2007) Model Pembelajaran Inovatif Berorientasi Konstruktivistif, Jakarta : Prestasi Pustaka

Uhbiyati, Nur. (1997) Ilmu Pendidikan Islam, Pustaka Setia, Bandung. 
Usman. (2000) Menjadi Guru Profesional. Bandung: Remaja Rosdakarya.

Uzer, Usman. (1990) Menjadi Guru Professional. Remaja Karya. Bandung.
Yusup, Pawit M. (2009) Ilmu Informasi, Komunikasi dan Kepustakaan. Jakarta : Bumi Aksara

Zuhairini, dkk, (1991) Filsafat Pendidikan Islam, Jakarta: Bumi Aksara. 